\title{
Zasady udzielania świadczeń zdrowotnych na rzecz osób bezdomnych
}

\section{Sebastian Sikorski*}

\begin{abstract}
Streszczenie: Problematyka dotycząca zasad udzielania świadczeń opieki zdrowotnej finansowanych ze środków publicznych jest złożona i wielowątkowa. Celem niniejszego artykułu jest przedstawienie tylko pewnego fragmentu tych zagadnień, a mianowicie podstaw prawnych udzielania świadczeń opieki zdrowotnej finansowanych ze środków publicznych, na rzecz osób bezdomnych. Z przeprowadzonej analizy obowiązujących w tym zakresie rozwiązań prawnych wynika, że obowiązuje tylko jedna podstawa prawna w tym zakresie dedykowana wprost osobom bezdomnym, tj. objęcie ubezpieczeniem zdrowotnym w ramach indywidualnego programu wychodzenia z bezdomności, która w praktyce ze względu na zakres zastosowania odgrywa jednak niewielką rolę. Pozostałe rozwiązania prawne są przewidziane dla szerszej kategorii osób, do której można także zaliczyć właśnie osoby bezdomne. W wyniku przeprowadzonej analizy zostaną zgłoszone postulaty de lege ferenda, w zakresie wywołującym największe trudności stosowania w praktyce przepisów regulujących te zagadnienia.
\end{abstract}

Słowa kluczowe: osoby bezdomne, finansowanie świadczeń opieki zdrowotnej, środki publiczne, Narodowy Fundusz Zdrowia.

\section{Wprowadzenie}

Na gruncie obowiązujących rozwiązań prawnych w zakresie udzielania świadczeń opieki zdrowotnej finansowanych ze środków publicznych, najliczniejszą grupą osób uprawnionych do korzystania z tych świadczeń stanowią osoby objęte obowiązkowym i dobrowolnym ubezpieczeniem zdrowotnym. Przy czym jako ubezpieczonych należy traktować zarówno osoby, które odprowadzają składkę na obowiązkowe i dobrowolne ubezpieczenie zdrowotne, jak i członków rodziny takich osób. Oprócz osób ubezpieczonych, prawo do świadczeń opieki zdrowotnej finansowanych ze środków publicznych mają także osoby spełniające określone kryteria, w tym kryterium dochodowe. Dla porządku należy w tym miejscu podkreślić, że szczególnym przypadkiem są sytuacje nagłego zagrożenia zdrowia i życia, gdzie świadczenia przysługują każdej osobie bez względu na fakt objęcia ubezpieczeniem zdrowotnym. W przypadku osób bezdomnych tylko jedno z obowiązujących rozwiązań jest adresowane wyłącznie do tej kategorii osób. Jest to przypadek objęcia ubezpieczeniem zdrowotnym (a w konsekwencji nabycie prawa do świadczeń) w ramach indywidualnego programu wychodzenia z bezdomności. Nawiasem mówiąc, ten sposób objęcia ubezpieczeniem zdrowotnym osób bezdomnych odgrywa

\footnotetext{
* Sebastian Sikorski

Katedra Prawa Administracyjnego i Samorządu Terytorialnego

Wydział Prawa i Administracji

Uniwersytet Kardynała Stefana Wyszyńskiego w Warszawie

ul. Wóycickiego 1/3, bud. 17, 01-938 Warszawa e-mail: sebastian_sikorski@onet.pl
} 
w praktyce relatywnie niewielką rolę. Pozostałe rozwiązania prawne dotyczą już szerszego kręgu osób, do których można zaliczyć także osoby bezdomne. Kluczowym rozwiązaniem w tym zakresie jest decyzja wójta, burmistrza bądź prezydenta gminy właściwej ze względu na miejsce zamieszkania, na mocy której osoba bezdomna uzyskuje czasowe potwierdzenie prawa do świadczeń opieki zdrowotnej finansowanych ze środków publicznych. Obowiązujące w tym zakresie przepisy wymagają jednak pewnego doprecyzowania w zakresie daty, od której liczone będzie obowiązywanie takiej decyzji, właściwości miejscowej organu oraz podmiotu uprawnionego o wystąpienie z wnioskiem o wydanie przedmiotowej decyzji na rzecz określonej osoby. Przedstawione zostaną również rozwiązania przewidziane na gruncie przepisów szczególnych, w zakresie terapii leczenia uzależnień oraz działania systemu Państwowego Ratownictwa Medycznego.

\section{Prawo do świadczeń zdrowotnych na gruncie Konstytucji Rzeczpospolitej Polskiej}

Biorąc pod uwagę zasadę hierarchiczności budowy systemu prawnego analizę problematyki dotyczącej zasad udzielania świadczeń opieki zdrowotnej udzielanych na rzecz osób bezdomnych, należy rozpocząć od Konstytucji Rzeczpospolitej Polskiej z dnia 2 kwietnia 1997 r. ' Zasadnicze znaczenie ma tutaj przepis art. 68 Konstytucji. Zgodnie z ust. 1 tego przepisu ustrojodawca zagwarantował każdemu prawo do ochrony zdrowia. Z kolei zgodnie z ust. 2 na władze publiczne został nałożony obowiązek zapewnienia równego dostępu dla wszystkich obywateli do świadczeń opieki zdrowotnej finansowanych ze środków publicznych, i to bez względu na ich sytuację materialną. Natomiast w ust. 3 zagwarantowano szcze-

Dz.U. z 1997 r. nr 78 poz. 483 z późn. zm. gólną opiekę zdrowotną na rzecz dzieci, kobiet ciężarnych, osób niepełnosprawnych i osób w podeszłym wieku. Z ujęcia takiego wynika kilka konsekwencji. Po pierwsze, ustrojodawca zagwarantował każdej osobie prawo do zdrowia, rozumiane jako prawo do ochrony biologicznej egzystencji człowieka, a w konsekwencji - powiązane z tym prawem - prawną ochronę godności człowieka wynikającą z przepisu art. 30 Konstytucji oraz ochronę życia ludzkiego ustanowioną w przepisie art. 38 Konstytucji. Prawo do zdrowia rozumiane jest także jako prawo do ratowania czy dbania o zdrowie. Podkreślenia wymaga fakt, że prawo do zdrowia jest prawem zagwarantowanym na rzecz każdej osoby. W doktrynie jak i orzecznictwie podkreśla się, że „na organach państwa spoczywa obowiązek stanowienia takiego prawa, by chroniło ono życie, i to życie każdego człowieka niezależnie od tego, w jakiej sytuacji znajduje się" [Boć, 1998, s. 78]. Odrębnym prawem, chociaż funkcjonalnie powiązanym z prawem do ochrony zdrowia, jest prawo do świadczeń opieki zdrowotnej finansowanych ze środków publicznych, wynikające z przepisu art. 68 ust. 2 Konstytucji. Należy podkreślić, że pomimo iż ustrojodawca bardzo szeroko zakreślił krąg osób uprawnionych do tych świadczeń, niezależnie od ich wieku, zawodu, wykonywanej pracy etc., to jednak, w przeciwieństwie do prawa do ochrony zdrowia, zawęził to prawo do osób posiadających obywatelstwo polskie.

Na tle sformułowania przepisu art. 68 ust. 2 Konstytucji można wyinterpretować normę nakazującą skonstruowanie takiego systemu opieki zdrowotnej, który uwzględnia, jako podstawową dyrektywę, równość dostępu do świadczeń. Jak słusznie podkreśla D.E. Lach, istotą (minimum) wynikającego z tego przepisu jest „nakaz stworzenia przez władze publiczne systemu opieki zdrowotnej, który będzie finansowany ze środków publicznych (stworzenie mechanizmu pozwalającego na gromadzenie i wydatkowanie na świadczenia 
opieki zdrowotnej środków publicznych, przy czym niedopuszczalne jest w zasadzie oparcie go na całkowicie wolnorynkowych zasadach) i zapewni równy dostęp do świadczeń opieki zdrowotnej" [Lach, 2016, s. 147]. Jednocześnie należy bardzo wyraźnie podkreślić, że zasady korzystania z tych świadczeń są de facto niezależne od zakresu udziału poszczególnych obywateli w finansowaniu funkcjonującego systemu ochrony zdrowia. Ustawodawca nie może więc wprowadzać (w ramach tego systemu) modelu pozwalającego na dyferencjację świadczeń w wypadku występowania podobnych potrzeb zdrowotnych [Sygit, Wąsik, 2016, s. 16-17]. Pewne uprzywilejowanie jest podyktowane troską o zapewnienie rozwoju narodu bądź względami humanitarnymi [Skrzydło, 2013, LEX/ el.] i wynika wprost z postanowień przepisu art. 68 ust. 3 Konstytucji, który nakazuje objąć szczególną ochroną (a więc występuje tu pewne uprzywilejowanie) dzieci, kobiety ciężarne, osoby niepełnosprawne i w podeszłym wieku. Oznacza to, że osoby bezdomne powinny być traktowane jak każdy obywatel, nie mając w tym zakresie na gruncie Konstytucji szczególnych uprawnień.

\section{Zasady udzielania świadczeń zdrowotnych w świetle ustawy o świadczeniach opieki zdrowotnej finansowanych ze środków publicznych}

Szczegółowe zasady oraz zakres finansowania świadczeń zdrowotnych określa ustawa z dnia 27 sierpnia 2004 r. o świadczeniach opieki zdrowotnej finansowanych ze środków publicznych ${ }^{2}$. W świetle tej ustawy najliczniejszą grupą osób uprawnionych do otrzymania świadczeń opieki zdrowotnej finansowanych ze środków publicznych są osoby objęte obowiązkowym i dobrowolnym ubezpieczeniem zdrowotnym (art. 2

Dz.U. z 2017 r. poz. 1938 t.j. z późn. zm., dalej: u.ś.o.z. ust. 1 pkt 1), które ustawodawca określa mianem ubezpieczonych [Kowalska-Mańkowska, 2016, LEX/el.]. W przypadku osób bezdomnych niebędących ubezpieczonymi, kluczowe znaczenie mają rozwiązania przewidziane na gruncie tej ustawy, pozwalające przyznać im prawo do otrzymania świadczeń zdrowotnych finansowanych ze środków publicznych na podstawie decyzji administracyjnej. Przepisem mającym tutaj zasadnicze znaczenie jest art. 54 u.ś.o.z. ust. 1. zgodnie z którym prawo do świadczeń opieki zdrowotnej świadczeniobiorcy mogą nabyć w drodze decyzji wójta (burmistrza, prezydenta) gminy właściwej ze względu na miejsce zamieszkania. Ponadto z ust. 3 tego przepisu wynika, że organ ten wydaje decyzję po przedłożeniu przez świadczeniobiorcę dokumentów potwierdzających zamieszkiwanie na terytorium Rzeczypospolitej Polskiej oraz dokumentów potwierdzających m.in. przeprowadzenie rodzinnego wywiadu środowiskowego, stwierdzenie spełniania kryterium dochodowego. W odniesieniu do osób bezdomnych potwierdzenie miejsca zamieszkania stanowi trudność niejako z założenia. Miejsce zamieszkania jest bowiem tutaj definiowane według prawa cywilnego. Każdy więc dokument potwierdzający, że dana osoba przebywa w danej miejscowości z zamiarem stałego pobytu, będzie dokumentem potwierdzającym fakt zamieszkania. Wątpliwości jednak budzi okoliczność, czy ustawodawca zobowiązuje świadczeniobiorcę do dostarczenia do gminy dokumentu urzędowego czy prywatnego. Dlatego wskazuje się, że dokumenty potwierdzające obywatelstwo i zamieszkiwanie winny być dokumentami urzędowymi, choć nie można wykluczyć wyjątków - fakt zamieszkania mogłyby potwierdzać na przykład zaświadczenia wydawane przez społeczne noclegownie czy domy opieki [Łukasik, Nowak-Kubiak, 2006, ABC/el.]. Wydaje się, że jest to jednak niepotrzebne utrudnienie $w$ odniesieniu do osób bezdomnych. W przypadku bowiem 
tych osób decydujące powinno być miejsce pobytu i według tego kryterium powinna być rozstrzygana także właściwość miejscowa organu. Zmiany wymaga też uprawnienie do złożenia wniosku o wydanie decyzji. Zgodnie bowiem z przepisem art. 54 ust. 4 u.ś.o.z. uprawnienie do złożenia wniosku o wydanie decyzji potwierdzającej prawo do świadczeń opieki zdrowotnej przysługuje co do zasady świadczeniobiorcy, a w przypadku stanu nagłego - także świadczeniodawcy. Z praktycznego punktu widzenia należałoby opowiedzieć się za rozwiązaniem, zgodnie z którym uprawnionym o wydanie takiej decyzji powinien być także świadczeniodawca i to bez względu na okoliczności udzielania świadczenia, czyli także w przypadkach innych niż stan nagły. Występują bowiem często sytuacje, w których osoba bezdomna opuszcza szpital bez złożenia wniosku o przedmiotową decyzję. Wówczas świadczeniodawca może mieć trudność z uzyskaniem finansowania udzielonych świadczeń. Najistotniejszy jest jednak problem związany z ustaleniem okresu uprawnienia do świadczeń. Zgodnie z przepisem art. 54 ust. 7 u.ś.o.z. prawo do świadczeń opieki zdrowotnej na podstawie wskazanej powyżej decyzji przysługuje przez okres 90 dni, licząc od dnia określonego w decyzji, którym jest: 1) dzień złożenia wniosku, 2) w przypadku udzielania świadczeń w stanie nagłym - dzień udzielenia świadczenia, chyba, że w tym okresie świadczeniobiorca zostanie objęty ubezpieczeniem zdrowotnym.

Nie budzi wątpliwości przypadek, w którym wniosek jest składany jeszcze przed uzyskaniem świadczenia zdrowotnego, a samo świadczenie udzielane jest dopiero na podstawie wydanej decyzji. Jednak trudności pojawiają się w odwrotnej sytuacji, która nawiasem mówiąc występuje bardzo często. Mianowicie, gdy świadczenie udzielane jest jeszcze przed wydaniem decyzji. Należy w tym miejscu nadmienić, że w doktrynie podnosi się również okoliczność samego toku postępowania, tj. zgodnie z kodeksem postępowania administracyjnego decyzja jest wydawana w okresie od dwóch tygodni do dwóch miesięcy, udzielane świadczenia zdrowotne w toku postępowania powinny być więc objęte tą decyzją [Łukasik, Nowak-Kubiak, 2006, ABC/el.]. Wydaje się, że w takim przypadku konieczne jest wydanie decyzji za okres, gdy świadczenie było udzielane. Jednak ustawodawca wprost tego nie przesądza [ibidem], co w praktyce nastręcza wiele trudności. Dlatego zasadny jest postulat zobowiązujący z jednej strony wnioskodawcę do wskazywania okresu objęcia uprawnieniem do świadczeń. Z drugiej zaś zobowiązujący organ do każdorazowego określenia daty, od której okres 90 dni uprawniający do świadczeń będzie liczony, tj. za okres faktycznego udzielania świadczeń.

Należy w tym miejscu wyraźnie podkreślić, że uzyskanie przedmiotowej decyzji wójta (burmistrza, prezydenta) właściwej gminy nie jest konieczne w sytuacji świadczeń udzielanych świadczeniobiorcy przez jednostki systemu Państwowego Ratownictwa Medycznego w warunkach pozaszpitalnych. Świadczenia te są zawsze udzielane nieodpłatnie i w konsekwencji zbędne jest przedstawianie przez świadczeniobiorcę decyzji w celu uzyskania bezpłatnie prawa do świadczeń tego rodzaju [Kowalska-Mańkowska et al., 2016, LEX/el.].

Inną podstawę do objęcia ubezpieczeniem zdrowotnym osoby bezdomnej stanowi przepis art. 66 ust. 1 pkt 29 u.ś.o.z., zgodnie z którym obowiązkowi ubezpieczenia zdrowotnego podlegają osoby bezdomne wychodzące z bezdomności, a niepodlegające obowiązkowi ubezpieczenia zdrowotnego $z$ innego tytułu. Ustawodawca zdefiniował w przepisie art. 5 pkt. 19 u.ś.o.z. osobę bezdomną wychodzącą z bezdomności jako osobę objętą indywidualnym programem wychodzenia z bezdomności zgodnie z przepisami ustawy z dnia 12 marca 2004 r. 
o pomocy społecznej ${ }^{3}$. Kluczowy w tym zakresie jest przepis art. 49 u.p.s., określający formy pomocy społecznej adresowanej do osób bezdomnych. W piśmiennictwie wskazuje się, że chociaż ustawa o pomocy społecznej wymienia bezdomność jako jedną z podstawowych okoliczności uzasadniającą udzielenie pomocy społecznej (art. 7 pkt 3), to poświęca relatywnie niewiele miejsca samemu zwalczaniu tego zjawiska [Maciejko, Zaborniak, 2013, LexisNexis/el.]. Udzielnie pomocy osobie bezdomnej w postaci dostarczenia ubrania, schronienia, posiłku nie likwiduje samego zjawiska bezdomności. Natomiast indywidualny program wychodzenia z bezdomności jest nakierowany właśnie nie tylko na doraźną pomoc, ale przede wszystkim na zwalczanie samego zjawiska bezdomności. W sensie formalnym indywidualny program wychodzenia z bezdomności jest dokumentem urzędowym, który jest sporządzany dla określonej osoby. Program ten powinien określać sposób współdziałania osoby nim objętej z organem, która ma na celu uzyskanie przez bezdomnego stałego zamieszkania oraz osiąganie dzięki pracy zarobkowej stałych dochodów pozwalających na samodzielne utrzymywanie się [Sierpowska, 2014, LEX/el.] Ustawodawca nie określa, w jaki sposób udzielana jest pomoc osobie objętej indywidualnym programem wychodzenia z bezdomności, dopuszcza więc wszelkie możliwe formy wsparcia. Jednoznacznie określoną przez ustawodawcę formą pomocy jest objęcie osoby realizującej indywidualny program wychodzenia z bezdomności obowiązkowi ubezpieczenia zdrowotnego. W doktrynie zasadnie wskazuje się, że nie jest do końca jasna relacja pomiędzy ust. 5 i 8 przepisu art. 49 u.p.s. Nasuwa się bowiem uzasadniona wątpliwość w zakresie interpretacji zwrotu: „jeśli zachodzi konieczność objęcia osoby bezdomnej ubezpieczeniem zdrowotnym" w świetle obowiązku opłacania składki na ubezpieczenie zdrowotne za taką osobę.

Dz.U. z 2017 r. poz. 1769 t.j. z późn. zm., dalej: u.p.s.
Zgodnie z art. 73 pkt. 11 u.ś.o.z obowiązek ubezpieczenia wymienionych osób powstaje od dnia rozpoczęcia realizacji indywidualnego programu wychodzenia z bezdomności, a wygasa z dniem jego zakończenia lub zaprzestania realizacji. Podstawą wymiaru składek na ubezpieczenie zdrowotne dla osób objętych indywidualnym programem wychodzenia z bezdomności jest maksymalna kwota zasiłku stałego z pomocy społecznej [Sierpowska, 2014, LEX/el]. W praktyce, na tej podstawie niewiele jednak osób bezdomnych zostaje objętych ubezpieczeniem zdrowotnym, a w konsekwencji nabywa prawo do świadczeń opieki zdrowotnej finansowanych ze środków publicznych. Programy te nie cieszą się bowiem dużym zainteresowaniem. Zdaniem przywoływanej już powyżej I. Sierpowskiej jest to spowodowane być może tym, że osoby, do których są adresowane, nie są skłonne do zmiany stylu życia, zwłaszcza zaś do wyzwolenia się z nałogów i podjęcia pracy.

\section{3. Świadczenia zdrowotne udzielane na podstawie przepisów szczególnych}

Ostatnią z analizowanych podstaw prawnych regulujących zasady nabywania uprawnień do świadczeń opieki zdrowotnej są przepisy szczególne, uszeregowane jako katalog zamknięty w przepisie art. 12 u.ś.o.z. W tym miejscu jedynie tytułem przykładu można wskazać następujące podstawy prawne do udzielania świadczeń: przepis art. 21 ust. 3 ustawy z dnia 26 października 1982 r. o wychowaniu w trzeźwości i przeciwdziałaniu alkoholizmowi ${ }^{4}$, przepis art. 26 ust. 5 ustawy z dnia 29 lipca 2005 r. o przeciwdziałaniu narkomanii ${ }^{5}$, bądź też przepisy ustawy z dnia 5 grudnia 2008 r. o zapobieganiu oraz zwalczaniu zakażeń i chorób zakaź-

\footnotetext{
4 Dz. U. z 2016 r. poz. 487 t.j. z późn. zm. 5 Dz. U. z 2017 r. poz. 783 t.j. z późn. zm.
} 
nych u ludzi ${ }^{6}$ oraz przepisy ustawy z dnia 8 września 2006 r. o Państwowym Ratownictwie Medycznym ${ }^{7}$. Już z samych tytułów zawartych w tym katalogu ustaw wynika, że przepisy te nie są adresowane wprost do osób bezdomnych. Jednak biorąc pod uwagę fakt, że bezdomność jest cechą położenia społecznego, łączącą się zwykle z różnorodnymi rodzajami patologii indywidualnej jak alkoholizm czy narkomania [Maciejko, Zaborniak, 2013, LexisNexis/el.], niektóre z tych przepisów należy również brać pod uwagę, jako dające podstawę otrzymania świadczeń opieki zdrowotnej. Z względu na objętość niniejszego artykułu w tym miejscu zostaną jedynie zasygnalizowane rozwiązania uregulowane na gruncie trzech ustaw, a mianowicie ustawy o wychowaniu w trzeźwości i przeciwdziałaniu alkoholizmowi, ustawy o narkomanii oraz ustawy o PRM.

Zgodnie z przepisem art. 21 ust. 3 ustawy o wychowaniu w trzeźwości i przeciwdziałaniu alkoholizmowi, od osób uzależnionych od alkoholu nie pobiera się opłat za świadczenia w zakresie leczenia odwykowego udzielane przez podmioty określone w ust. 1, tj. podmioty lecznicze wykonujące działalność leczniczą w rodzaju świadczenia stacjonarne i całodobowe oraz ambulatoryjne w rozumieniu przepisów o działalności leczniczej. Przepis ten wprowadza więc wyjątek od zasady, iż bezpłatne świadczenia opieki zdrowotnej przysługują osobom ubezpieczonym. Bezpłatny charakter tego typu świadczeń na rzecz osób uzależnionych od alkoholu w zakresie lecznictwa odwykowego ma na celu umożliwienie podjęcia decyzji o poddaniu się leczeniu odwykowemu również i tym osobom, które bardzo często wskutek uzależnienia od alkoholu utraciły pracę i nie są ubezpieczone $z$ innych tytułów. Za takim rozwiązaniem przemawia więc aspekt społeczny, umożliwiający takim

6 Dz. U.z 2016 r. poz. 1866, 2003 i 2173.

Dz.U. z 2017 r. poz. 2195 t.j. z późn. zm., dalej: ustawa o PRM. osobom (znajdującym się często w krytycznej sytuacji materialnej) podjęcie leczenia choroby alkoholowej [Skrzydło-Niżnik, Zalas, 2002, Zakamycze/el.]. Zgodnie z aktem wykonawczym do tej ustawy, tj. rozporządzeniem Ministra Zdrowia z dnia z dnia 25 czerwca 2012 r. w sprawie organizacji, kwalifikacji personelu, sposobu funkcjonowania i rodzajów podmiotów leczniczych wykonujących świadczenia stacjonarne i całodobowe oraz ambulatoryjne w sprawowaniu opieki nad uzależnionymi od alkoholu oraz sposobu współdziałania w tym zakresie $\mathrm{z}$ instytucjami publicznymi i organizacjami społecznymi ${ }^{8}$ świadczenia te obejmują działania diagnostyczne, korekcyjne, indywidualne świadczenia zapobiegawczo-lecznicze, programy psychoterapii oraz działania konsultacyjno-edukacyjne. Należy jednak zaznaczyć, że osoba, która nie jest objęta ubezpieczeniem zdrowotnym i nie posiada innego tytułu do korzystania ze świadczeń opieki zdrowotnej finansowanych ze środków publicznych, a jest uzależniona od alkoholu, może korzystać z bezpłatnej publicznej opieki zdrowotnej, ale jedynie w zakresie świadczeń leczenia odwykowego. W odniesieniu do pozostałych świadczeń zastosowanie mają powyżej analizowane przepisy dotyczące objęcia ubezpieczeniem zdrowotnym. Podobne rozwiązania zostały zawarte także na gruncie ustawy o przeciwdziałaniu narkomanii w odniesieniu do osób uzależnionych od narkotyków, środków odurzających, psychotropowych oraz tzw. prekursorów. Zgodnie z przepisem art. 26 ust. 5 tej ustawy, za świadczenia, leczenie, rehabilitację lub reintegrację osoby uzależnionej niezależnie od jej miejsca zamieszkania w kraju nie pobiera się od tej osoby opłat. Ostatnią z regulacji wymagającej zasygnalizowania w tym miejscu jest ustawa o PRM, której przepisy nakładają obowiązek niezwłocznego udzielenia pomocy osobie znajdującej się w stanie nagłego zagrożenia zdro-

Dz.U.z 2012 r. poz. 734 
wotnego w rozumieniu przepisu art. 3 pkt 8 tejże ustawy. Stan ten został definiowany jako „stan polegający na nagłym lub przewidywanym w krótkim czasie pojawieniu się objawów pogarszania zdrowia, którego bezpośrednim następstwem może być poważne uszkodzenie funkcji organizmu lub uszkodzenie ciała lub utrata życia, wymagający podjęcia natychmiastowych medycznych czynności ratunkowych i leczenia". Z brzmienia przywołanego powyżej przepisu art. 12 u.ś.o.z. wynika, że każdej osobie znajdującej się $\mathrm{w}$ takim stanie przysługują medyczne czynności ratunkowe oraz leczenie. $W$ tym miejscu należy podkreślić, że czynnościami ratunkowymi są świadczenia zdrowotne udzielane przez zespoły ratownictwa medycznego w warunkach pozaszpitalnych, w celu ratowania osoby znajdującej się w stanie nagłego zagrożenia zdrowotnego. Natomiast osobie w stanie nagłym przysługują również świadczenia zdrowotne określane jako leczenie. Ustawodawca nie wprowadza w tym zakresie już żadnych ograniczeń ani co do miejsca udzielania świadczeń, ani co do podmiotu udzielającego, a tym samym zakresu świadczeń [Kowalska-Mańkowska, 2016, LEX/el.].

\section{Podsumowanie}

Z przeprowadzonej analizy wynika, że ustrojodawca w Konstytucji oraz ustawodawca zwykły, co do zasady nie wyróżnia szczególnych zasad udzielania świadczeń opieki zdrowotnej na rzecz osób bezdomnych. Najczęściej osoby te nabywają uprawnienia do świadczenia na podstawie decyzji wójta (burmistrza lub prezydenta) właściwej gminy wydanej na podstawie przepisu art. 54 ust. 1 u.ś.o.z., obok szerszego kręgu osób uprawnionych do wnioskowania o wydanie takiej decyzji. Zgodnie z ust. 7 tego przepisu, prawo do świadczeń opieki zdrowotnej na podstawie przedmiotowej decyzji przysługuje przez okres 90 dni, licząc od dnia określonego w decyzji, którym jest: dzień złożenia wniosku, a w przypadku udzielania świadczeń w stanie nagłym jest to dzień udzielenia świadczenia. Chyba, że w tym okresie świadczeniobiorca zostanie objęty ubezpieczeniem zdrowotnym. Zgodnie z tym, co zostało już wskazane powyżej, przepisy obowiązujące w tym zakresie wymagają jednak pewnego doprecyzowania. Nie budzi bowiem zastrzeżeń sytuacja, w której wniosek jest składany jeszcze przed uzyskaniem świadczenia zdrowotnego, a samo świadczenie udzielane jest dopiero na podstawie wydanej decyzji. W praktyce jednak bardzo często występuje sytuacja dokładnie odwrotna, gdy świadczenie udzielane jest jeszcze przed wydaniem decyzji. Wydaje się, że w takim przypadku konieczne jest wydanie decyzji za okres, gdy świadczenie było udzielane. Ustawodawca nie określa jednak tego wprost, co może powodować wiele trudności. Dlatego należy postulować, aby co do zasady wnioskodawca był zobowiązany do wskazania okresu objęcia uprawnieniem do świadczeń. Natomiast organ powinien każdorazowo wskazać w decyzji datę, od której będzie liczony okres 90 dni uprawniający do świadczeń. Kolejnym postulatem jest szersze dopuszczenie możliwości składania wniosku o wydanie przedmiotowej decyzji przez świadczeniodawcę, w którego interesie jest uzyskanie podstawy prawnej do zwrotu kosztów leczenia takiej osoby przez Narodowy Fundusz Zdrowia (dalej: NFZ). Również sposób wyznaczania właściwości miejscowej według miejsca zamieszkania wydaje się niepotrzebną komplikacją w odniesieniu do osób bezdomnych. Za wystarczające należałoby uznać miejsce pobytu takiej osoby.

Kolejnym sposobem nabycia uprawnień do świadczeń opieki zdrowotnej (chociaż, jak wynika z praktyki, mającym znacznie rzadsze zastosowanie) jest objęcie ubezpieczeniem zdrowotnym w ramach programu wychodzenia z bezdomności, tj. na podstawie przepisu art. 66 ust. 1 pkt 29 u.ś.o.z. W praktyce 
jednak na tej podstawie niewiele osób bezdomnych nabywa uprawnienia do świadczeń opieki zdrowotnej finansowanych ze środków publicznych. Programy te nie cieszą się bowiem dużym zainteresowaniem.

Wreszcie osoby te mogą uzyskać świadczenia na podstawie przywołanych powyżej przepisów szczególnych wynikających z różnych aktów prawnych. Na przykład w zakresie leczenia uzależnień występujących relatywnie często pośród osób bezdomnych.

Patrząc z perspektywy świadczeniodawcy, a więc z punktu widzenia zasad finansowania świadczeń, rozróżnienie na świadczeniobiorców, którzy posiadają ubezpieczenie, i na świadczeniobiorców nieposiadających takiego ubezpieczenia, jak również na podmioty, które nabyły prawo do świadczeń na podstawie odrębnych przepisów, jest istotne ze względu na podmiot finansujący leczenie tych osób. Ponieważ wyłącznie w przypadku osób ubezpieczonych leczenie ich jest finansowane ze środków pochodzących ze składek na ubezpieczenie zdrowotne,

\section{Literatura}

Boć J. (red.) (1998). Konstytucje Rzeczypospolitej oraz komentarz do Konstytucji RP z 1997 roku. Wrocław: Kolonia Limited.

Lach D.E. (2016). Zasada równego dostępu do świadczeń opieki zdrowotnej. Kraków: Wydawnictwo Uniwersytetu Jagiellońskiego.

Kowalska-Mańkowska I. et al. (2016). Ustawa o świadczeniach opieki zdrowotnej finansowanych ze środków publicznych. Komentarz, wyd. III. LEX/el.

Łukasik B., Nowak-Kubiak J. (2006). Ustawa o świadczeniach opieki zdrowotnej finansowanych ze środków publicznych. Komentarz. ABC/el.

\section{Akty prawne}

Konstytucja Rzeczypospolitej Polskiej z dnia 2 kwietnia 1997 r., Dz.U. z 1997 r. nr 78 poz. 483 z późn. zm. Rozporządzenie Ministra Zdrowia z dnia 25 czerwca 2012 r. w sprawie organizacji, kwalifikacji personelu, sposobu funkcjonowania i rodzajów podmiotów leczniczych wykonujących świadczenia stacjonarne i całodobowe oraz ambulatoryjne w sprawowaniu którymi dysponuje NFZ. Natomiast świadczenia opieki zdrowotnej udzielone pozostałym świadczeniobiorcom uprawnionym do bezpłatnych świadczeń zdrowotnych, lecz niebędących osobami ubezpieczonymi, oraz osobom, którym na mocy przepisów odrębnych udzielane są świadczenia opieki zdrowotnej, podlegają także finansowaniu przez NFZ, lecz finansowanie to pochodzi ze środków budżetu państwa, z części, której dysponentem jest minister właściwy do spraw zdrowia, w formie dotacji, o której mowa w art. 97 ust. 8 u.ś.o.z., lub bezpośrednio przez ministra właściwego do spraw wewnętrznych, ministra właściwego do spraw zdrowia lub Ministra Sprawiedliwości ze środków budżetu państwa, z części, której są dysponentami. W przypadku więc osób nieubezpieczonych, świadczenia te są finansowane z budżetu na podstawie dotacji. Płatnik publiczny (NFZ) wówczas jedynie pośredniczy przy dokonywaniu zapłaty za wykonane na rzecz tych osób świadczenia [Kowalska-Mańkowska et al., 2016, LEX/el.).

Maciejko W., Zaborniak P. (2013). Ustawa o pomocy społecznej. Komentarz, wyd. IV. LexisNexis/el.

Sierpowska I. (2014). Pomoc społeczna. Komentarz, wyd. III. LEX/el.

Skrzydło-Niżnik I., Zalas G. (2002). Ustawa o wychowaniu w trzeźwości i przeciwdziałaniu alkoholizmowi. Komentarz. Zakamycze/el.

Skrzydło W. (2013). Konstytucja Rzeczypospolitej Polskiej. Komentarz, wyd. VII. LEX/el.

Sygit B., Wąsik D. (2016). Prawo ochrony zdrowia. Warszawa: Difin.

opieki nad uzależnionymi od alkoholu oraz sposobu współdziałania w tym zakresie z instytucjami publicznymi i organizacjami społecznymi, Dz.U. z 2012 r. poz 734.

Ustawa z dnia 8 września 2006 r. o Państwowym Ratownictwie Medycznym, Dz.U. z 2017 r. poz. 2195 t.j. z późn. zm. 
Ustawa z dnia 22 września 2017 r. o pomocy społecznej, Dz.U. z 2017 r. poz. 1769 t.j. z późn. zm.

Ustawa z dnia 29 lipca 2005 r. o przeciwdziałaniu narkomanii, Dz. U. z 2017 r. poz. 783 t.j. z późn. zm.

Ustawa o z dnia 27 sierpnia 2004 r. o świadczeniach opieki zdrowotnej finansowanych ze środków publicznych, Dz.U. z 2017 r. poz. 1938 t.j. z późn. zm.
Ustawa z dnia 26 października 1982 r. o wychowaniu w trzeźwości i przeciwdziałaniu alkoholizmowi, Dz.U. z 2016 r. poz. 487 t.j. z późn. zm.

Ustawa z dnia 5 grudnia 2008 r. o zapobieganiu oraz zwalczaniu zakażeń i chorób zakaźnych u ludzi, Dz.U. z 2016 r. poz. 1866, 2003 i 2173.

\section{Rules of providing health services to homeless people}

Summary: The problem of providing healthcare services publicly funded is complex. The purpose of the article is the presentation of a certain fragment of these issues, which, in accordance with title, concerns the legal basis of providing healthcare services publicly funded for homeless people.

There is only one legal basis in this regard dedicated straight for the homeless people, namely providing health insurance under individual programme of recovering from homelessness, which in view of the extent of the application plays hardly any role. Other legal solutions are provided for a wider range of categories of people for which the homeless people can be classified. As a result of analysis, the demands de lege ferenda shall be made in the area causing the major difficulties of the application in practice of the rules governing these issues.

Keywords: homeless people, healthcare services funding, public funding, National Health Service.

\section{Prawa autorskie i licencja / Copyright and License}

Artykuł opublikowano na licencji Creative Commons

Uznanie autorstwa - Użycie niekomercyjne - Bez utworów zależnych 3.0 Polska

http://creativecommons.org/licenses/by-nc-nd/3.0/pl/

This article is published under the terms of the Creative Commons

Attribution - NonCommercial - NoDerivs (CC BY-NG-ND 3.0) License

http://creativecommons.org/licenses/by-nc-nd/3.0/ 